\section{Consumers' preferences for a local food product: the case of a new Carnaroli rice product in Lombardy}

\author{
Giovanni Ferrazzi, ${ }^{1}$ Vera Ventura, ${ }^{1}$ \\ Sabrina Ratti, ${ }^{2}$ Claudia Balzaretti ${ }^{2}$ \\ 'Department of Economics, \\ Managements and Quantitative \\ Methods, University of Milan, Milan; \\ ${ }^{2}$ Department of Health, Animal Science \\ and Food Safety, University of Milan, \\ Milan, Italy
}

\begin{abstract}
Italy, with a cultivated area of 218,000 ha, is a European leader of rice production. In particular Lombardy region accounts for $40 \%$ of total rice cultivation and the case study in object accounts for $3.2 \%$ of Lombardy total rice area (2773 ha). Starting from 2012, through a regional project titled Buono, Sano e Vicino (good, healthy and close), Riso e Rane rural district supported local rice farmers in developing innovation in rice production and promoting an alternative supply chain to increase farmers bargaining power and promote new market strategies. More specifically, the innovation introduced is a new biotech method for variety certification, named DNA controllato (DNA tested). In the first step of the project, the attention was focused on an Italian traditional variety of rice: Carnaroli rice. Thanks to a commercial agreement with one of the most important large retailers in Lombardy, the Riso e Rane rice is offered for sale both in the traditional and wholegrain version. In this context, this work aims to evaluate the determinants of consumer's quality perception of this product, through a preference study of the commercial rice package. Preliminary results reveal that consumers perceive information about origin, local food-system and tradition more easily than DNA tested certification. In conclusion, this work contributes to evaluate the role of bio economy applications to the food sector and offers new insights for the debate about the relationships between tradition and innovation.
\end{abstract}

\section{Introduction}

Italy is the European leader for rice cultivation with $1,339,000$ tons $(48 \%)$ of $\mathrm{EU}$ total production. The other relevant rice producers EU Countries are Spain (30\%) and Portugal (8\%) (Eurostat, 2014). Rice cultivation in Italy is particularly concentrated in Vercelli, Novara, Pavia and Milano, the rice-growing areas further north around the world. In Italy about 70 different varieties of rice of both japonica and indica type are cultivated. Within the japonica, some varieties such as Arborio, Carnaroli and Vialone Nano are considered the most valuable for the preparation of the most typical Italian dishes. Nevertheless, the extreme fragmentation of rice producers is a great obstacle for the competitiveness of the rice supply chain. In this scenario, the development of rural districts can be considered a strategic element for the concentration of agricultural production, and the key role of farmers' networks as driving force for the implementation of local food systems (LAS) is confirmed by several previous studies (CIRAD-SAR, 1996; Dunne et al., 2010; Feenstra, 2002: Hardesty, 2008). In 2012, Riso e Rane rural district won a regional project titled Buono, Sano e Vicino (good, healthy and close) with the aim to help local rice farmers developing an alternative supply chain in which the District, acting as a local player, helps to increase farmers bargaining power and promote new market strategies. The attention was focused on traditional Lombardy rice varieties: Carnaroli, Arborio, Baldo, Roma, Sant'Andrea, Vialone Nano. In particular, Riso e Rane rural district chose Carnaroli rice variety as the most representative example of this new model of agricultural chain, according to the evidences derived from a preliminary market research. The project was finalized to underline the principal characteristics of this product, identify the most important elements of innovation and define a common strategy at district level. The actions promoted within the project aim at defining a virtuous path oriented to product/process quality, enabling the District's farmers to differentiate their production at market level. Moreover, local and traditional attributes could be able to attract urban consumers allowing the product to be recognized and appreciated on the national and international market for its qualitative and traditional peculiarities.

The final output is represented by a new commercial product, consisting of $100 \%$ Carnaroli variety, certified thanks to a new biotech technology. More specifically, the DNA Tested technology certifies with a DNA analysis on seeds that the rice contained in the pack exactly corresponds to the variety indicated on label. The DNA test allow the Riso e Rane rural district to guarantee to the consumer the actual presence of the Carnaroli variety and the exclusion of varieties that are similar in product category
Correspondence: Giovanni Ferrazzi, Department of Economics, Managements and Quantitative Methods, University of Milan, Via Festa del Perdono 7, 20122 Milan, Italy. Tel: +39.320 .0626472$

E-mail: giovanni.ferrazzi@unimi.it

Key words: Innovation; Consumer; Tradition; Rice.

Received for publication: 21 July 2016. Accepted for publication: 16 December 2016.

This work is licensed under a Creative Commons Attribution-NonCommercial 4.0 International License (CC BY-NC 4.0).

(C) Copyright G. Ferrazzi et al., 2017

Licensee PAGEPress, Italy

Italian Journal of Food Safety 2017; 6:6186

doi:10.4081/ijfs.2017.6186

but not in substance, such as: Carnise, Karnak, and Poseidone that belong to the same commercial group as Carnaroli (superfine Group) rice. Thanks to a commercial agreement with one of the most important player of large scale distribution in Lombardy region, the Riso e Rane rice is offered for sale both in the traditional and whole-grain version.

Building on the above-described scenario the present work aims at investigating consumers' acceptance toward this product, by understanding the different contribution of the attributes (variety, origin, tradition, traceability,) on the quality perception of Riso e Rane rural district rice.

The results of this survey will allow the District to adapt the future packaging to the needs and tastes of consumers, even in view of a future supply expansion to other varieties of rice in the District.

In fact, understanding how consumers perceive food products is critical for food companies. This information is essential for the development and marketing of new products, the reformulation of existing products, the optimization of manufacturing processes and the establishment of specifications in quality control programmes (Meilgaard et al., 1999). For this reason, it is very important for a company to determine the level of consumer preference for a product. In fact, the knowledge of customer loyalty, preference and customers' price sensitivity, can reduce operating costs (Mohr, 1982). Consumer acceptance of a food is, however, dependent on many different factors, which may be related to the product itself, the consumer or the consumer environment (Ares et al., 2010). In particular, the sensory appeal of a food product and the visual appearance of its 
packaging are powerful influences on consumer acceptability (Cardello, 1994). Moreover, a higher value of customer satisfaction can improve the effectiveness of advertising, and enhances business reputation.

\section{Materials and Methods}

\section{Case study description}

The Riso e Rane rural district, born in 2011 , accounts for 62 rice farms located in 23 municipalities near Milan (Figure 1). Riso e Rane rural district rice production, with 2773 hectares, accounts for $23 \%$ of Milan (3.2\% of Lombardy) total rice area. Moreover, Riso e Rane rural district farms are characterised by higher values of UAA/farm in comparison with the regional and provincial mean data.

As previously described, the output of the project is represented by a new commercial product, consisting in Carnaroli rice, offered for sale both in the traditional and whole-grain version. Carnaroli rice branded Riso e Rane is a product characterized by tradition, quality and certification, identifiable by the consumer just looking at the package, able to differentiate this product from the rice products of major competitors. Thus, the aim of the analysis is to assess the perception of Carnaroli rice packaging by direct observation of the box, according to the outward appearance only, without the ability to open the package, or to taste the product contained inside. The packaging of the Carnaroli rice from the Riso e Rane rural district is designed precisely to emphasise the distinctive elements previously anticipated, fully consistent with the values reported in the project Distretto Riso e Rane-Buono, sano e vicino (Figure 2).

The front side of the packaging immediately conveys the strong link of the product with the territory. This strong territorial character is introduced by the District logo,

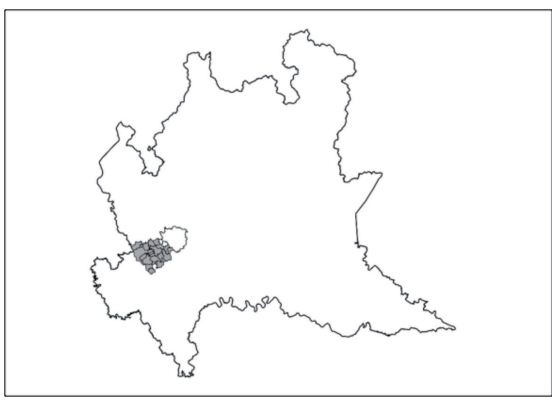

Figure 1. Riso e Rane rural district. composed of the stem of a rice plant on which rests a frog with the Milan Cathedral in the background, and it is even more marked from the map that shows the area of origin of the product, citing the names of the municipalities of the Agricultural District.

Great importance is given to the type of rice produced: Carnaroli, as the variety name appears in bold characters exactly in the centre of the front side, next to the $D N A$ tested logo, which certifies the full compliance of the product inside the packaging to Carnaroli variety.

The back of the package has been dedicated to the deepening of the distinctive characteristics of the product, anticipated in the front side of the pack: the consumer can find the detailed description of the certification DNA tested a guarantee of product quality, certified by the Padano Technology Park in Lodi, a research centre that brings together the main institutions active in the agro-biotech sector: from the University to the National Research Council, from Institutes for Experimental Veterinary Medicine of to private research units.

This label guarantees, through DNA analysis, the certification of the variety of rice in order to protect the consumer from possible fraud.

The front side of the Right shows the product name and other commercial information's such the conservation, the weight of the packaging and nutritional information, as required by Italian regulations regarding Commerce of Food Products.

At the top of the left side, with the aim to emphasize the local origin of the product the traditional recipe for Risotto alla Milanese is described.

The lower section of the pack shows the
Quick Response Code, a two-dimensional bar code that allows the consumer, through the smartphone, a trail for all information relating to the DNA tested technology.

\section{Consumers' preference analysis: characteristics of the sample and} aim

The analysis of the customer satisfaction on Riso e Rane Carnaroli rice was performed on a sample of 60 judges equally distributed according to sex and age. In particular, the interviews have seen the voluntary collaboration of 30 men and 30 women divided into 5 age groups, each consisting of 12 subjects, 6 male and 6 female. The aim of the interviews was to assess the Carnaroli rice packaging, by direct observation of the box, only according to the outward appearance, without the possibility to open the package, or to taste the product contained inside. At the time of the test the evaluated product was already on the market, so we decide to not revealed to the judges the price of the product or the place of sale within the large retail chains, in order to avoid the validity of the data. As evaluation and measurement instrument was adopted a questionnaire.

The direct survey consists in a questionnaire with nine questions of which seven closed questions and two open-ended questions. The sheet one of the questionnaire includes consumers' personal details, such as name, sex and age, as well as the date of completion.

Before the product evaluation, judges had to carefully observe the package than make a preference judgment based on the questions in the test evaluating each question with a score from 1 to 9, where 1 represents a totally bad judgment and 9 an
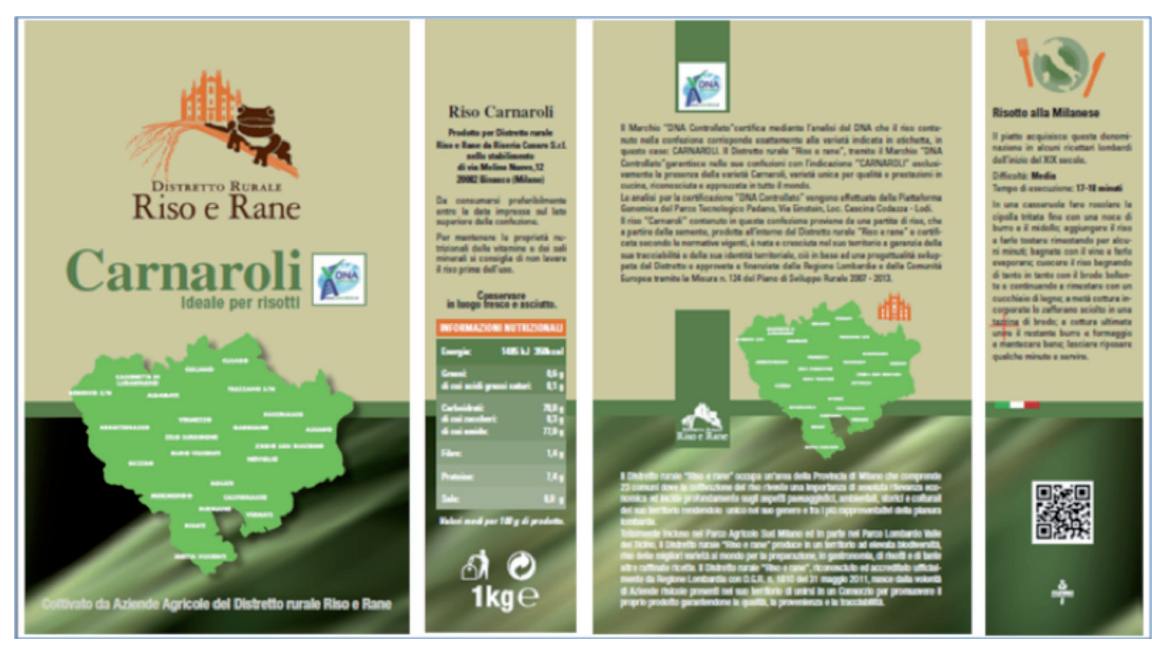

Figure 2. Layout of the Riso e Rane commercial product. 
extremely good judgment.

The first question asked for a global assessment on the characteristics and the package structure, while the subsequent questions were related to each one aspect: colour (question 2); logo (question 3); clarity of the information on the packaging (question 4); findings regarding the additional information such as, recipe, information on the District and the DNA certificate (question 5).

Unlike the first five questions, the question number 6 has no plans to make a score on a scale of liking, but just a summary judgment (YES/NO) on the possibility of purchasing the product.

Questions 7 and 8 have instead provided the possibility for the judge to freely express their views on the package, both in terms of the positive aspects (question 7), and in relation to the negative aspects (question 8).

Finally, question number 9 was intended to ask the judges an opinion on the segment of the market of large retailers in which you could enter the product, according to their personal point of view, placing a cross on the box corresponding to one of the following bands market: Lower, Middle low, High Middle, High.

Data came from direct survey were statistically analysed using SPSS (SPSS/PC Statistics 18.0 SPSS Inc., Chicago, IL, USA).

\section{Results and Discussion}

Results in Figure 3 show that the average scores for the global evaluation of the product are 6.23 and 6.67 for men and women, respectively.

Moreover, for all the parameters considered the mean values of customer evaluation are quite satisfactory, revealing an overall appreciation for this new Carnaroli rice product. More in general, women tend to express a higher degree of satisfaction for all the attributes under consideration.

As for the question concerning the positioning in the market segment of retail, the $78 \%$ of the sample assign the Riso e Rane rural district rice to a mid-high or high market sector. The satisfaction for the product is confirmed by the results of the willingness to purchase question, where the $72 \%$ of the sample answered positively.

Finally, the assessment of freely expressed opinions in the final questions of the survey (Table 1) reveals that the presence of the indication of the geographical area of production is the most liked element of the package, namely the one that most significantly contributes to the positive assessment of the product. Consumers also appreciated the large amount of information provided, in terms of richness: this aspect can be interpreted as a confirmation of the increasing consumer's demand for a better knowledge of the food products they are going to purchase, and the greater attention to the health/environmental implication of their consumption habits. Italians consumer demand for foods to fit their specific health needs and lifestyle will continue to increase and will have an impact on all sectors of food processing and manufacturing, and also on the supporting industries, as underlined by Annunziata and Pascale (2009).

On the opposite side, the global layout of the package is the factor that received the most negative comments: more specifically, consumers suggested to insert a window in order to see the rice product inside the box, reaffirming the abovementioned demand for transparency during the purchase of food products. These findings were in agreement with Tranner and Raymond (2016) who reported that consumer behaviour is influenced by many factors like: the layout of the product, grouping and availability of products, pricing, and advertising. As for the evaluation of the DNA logo, results are quite contrasting, revealing that the presence of the symbol of the DNA double helix could be perceived as an ambiguous element, that reminds to genetically modified products. Nevertheless, the same proportion of consumers show a positive perception of the DNA logo, and associate it to scientific research as guarantee for a better quality of the product.

\section{Conclusions}

This study shows that in a highly competitive market such as that of rice, characterised by a great variety of types of the same product sold in the context of mass retailers, the conquest of a market share and the creation of a relationship of trust with potential consumers also involves the exploitation of the geographical territoriality and the origin of the product. Nevertheless, certification and related information appear to be positive discriminant when buying a food product, particularly if the consumer is forced to choose between multiple types of the same product. Geographic identity, certifications and product information attributes have a positive influence on the choice of the product

Table 1. Customer evaluation, positive and negative attributes.

\begin{tabular}{lccccc} 
& Positive (\%) & Negative (\%) & Chi-square & P & Total \% \\
Clarity of information & 5.028 & 2.793 & 1.143 & 0.424 & 7.821 \\
Richness of information & 10.615 & 3.911 & 5.538 & 0.029 & 14.525 \\
\hline Market information & 3.911 & 2.793 & 0.333 & 0.774 & 6.704 \\
Layout & 13.408 & 29.609 & 10.922 & 0.001 & 43.017 \\
\hline DNA $\log 0$ & 5.587 & 5.028 & 0.053 & 1.000 & 10.615 \\
Origin & 13.408 & 3.911 & 9.323 & 0.003 & 17.318 \\
\hline
\end{tabular}

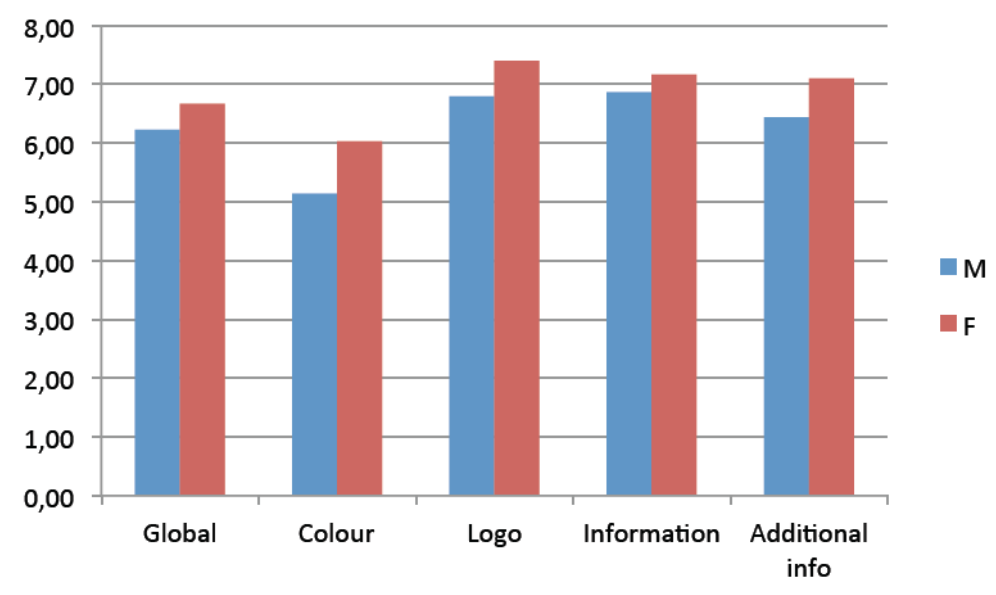

Figure 3. Customer evaluation, mean values. 
by the consumer. Indeed, the evaluation of the results obtained through the answers to the question concerning the possibility of a possible purchase of the product showed that $72 \%$ of respondents expressed their willingness to purchase the product. The commercialisation of a product that promotes the link with the territory and that refers to the Lombard agricultural tradition, like the Carnaroli rice branded Riso e Rane, can find placement in a medium-high market segment, successfully intercepting the quality requirements of the modern urban consumers.

\section{References}

Annunziata A, Pascale P, 2009. Consumers' behaviors and attitudes toward healthy food products: the case of organic and functional foods. In: Proc. of the 113th
EAAE Seminar A resilient European food industry and food chain in a challenging world. Chania, Crete, Greece, September 3-6.

Ares G, Giménez A, Barreiro C, Gámbaro A, 2010. Use of an open-ended question to identify drivers of liking of milk desserts. Comparison with preference mapping techniques. Food Qual Pref 21:286-94.

Cardello AV, 1994. Consumer expectations and their role in food acceptance. In: H.J.H. MacFie, D.M.H. Thompson (eds.) Measurement of food preferences. Blackie Academic Press, London, UK, pp. 253-97.

CIRAD-SAR, 1996. Systèmes agroalimentaires localisés: organisations, innovations et développement local. CIRADSAR, Montpellier, France.

Dunne J, Chambers K, Giombolini K, Schlegel S, 2010. What does 'local' mean in the grocery store? Multiplicity in food retailers' perspectives on sourcing and marketing local foods. Renew Agr Food Syst 26:46-59.

Eurostat, 2014. Available from: http://ec.europa.eu/eurostat

Feenstra G, 2002. Creating space for sustainable food systems: lessons from the field. Agr Hum Values 19:99-106.

Hardesty SD, 2008. The growing role of local food markets. Am J Agric Econ 90: 1289-95.

Meilgaard M, Civille GV, Carr BT, 1999. Sensory evaluation techniques. CRC Press, Boca Raton, FL, USA.

Mohr RB, 1982. Explaining organizational behavior. Jossey-Bass, San Francisco, CA, USA.

Tanner JF Jr., Raymond MA, 2016. Factors that influence consumers' buying behavior. In: J.F. Tanner Jr., M.A. Raymond (eds.) Principles of marketing, v. 2.0. Flatworld, Washington, DC, USA, chapter 3 . 